\title{
Museums and Online Spaces. The Society- Building Role of the Museums during the Pandemic
}

\author{
András VAJDA \\ Sapientia Hungarian University of Transylvania \\ Cluj-Napoca, Romania \\ e-mail: vajdandras@yahoo.com
}

\begin{abstract}
In the past more than six months, not only the cultural institutional network but also all of humanity has entered in a peculiar existential state. All that was previously commonplace, accepted, or natural has become in many ways impossible or, in some cases, even illegal. In the last period, we could also witness the changes regarding museums and museum environments, and we ourselves, who inhabit/use the spaces of the museums, have also changed. These changes affect the frameworks of representation and reception as well as our habits of viewing and interpretation. The pandemic has caused in museum practice a backward step towards a previous practice. Museums have suddenly re-become archives preserving objects and meanings, and it will take time for them to recollect themselves and start searching for solutions.
\end{abstract}

Keywords: pandemic situation, museum, digitization, virtualization, identity and authenticity

\section{o. Introduction}

The basic premise of this paper is that the museum is a space/construction which not only offers a location for objects that have fallen or have been taken out of use for various reasons and were transferred to various exhibitions, nor is a mere framework for museologists' or curators' work, but it also determines the meanings emerging during the work going on within it, both for the creator and the recipient. My main aim is to touch upon some problems of principle (partly methodological and partly theoretical) associated with the museum practice of the last half year, with the restriction that my suggestions are primarily based on, and valid for, experiences related to the practices of (ethnographic) museums dedicated to the exploration, presentation, and interpretation of the past (and primarily of folk culture) and, as such, of prime importance for the construction of national/regional/local identity. 


\section{On the Nature of Museums}

1. In order to explore the above-mentioned issues, I must first of all clarify the issues related to the nature of the museum. The social scientific description and analysis of museums as well as of the scientific and artistic work (if we accept that even exhibitions based on scientific research and presenting scientific results are to be viewed primarily as an artistic form of interpretation) taking place in museums has been carried out many times and in many ways. Several metaphors have been tried out for the description of the practices going on in the museum. Museums have been discussed in the context of the objects, the spectacle, the meanings, the movement(s), and the encounters ${ }^{1}$ alike. Additionally, the nature of the museum and of museum work has also been described based on the concept of the heritage factory (where meanings are produced and communicated in a process of ongoing recontextualization), ${ }^{2}$ of the theatre/stage (see Frazon, 2011: 67-92) (where the spectacle and the theatrical and the strident nature of the representation of the objects and meanings is of decisive importance), ${ }^{3}$ and of the mall model (where in addition to/instead of the exploration and presentation of meanings the increasing emphasis is on entertainment). At the same time, I should also mention here Richard Kurin's conception about the transmission of different forms of culture, in which the different types of cultural representation are discerned on the basis of three metaphorical expressions: expedition, flea market, and mediation (Fejôs, 2003b: 150-151.). All of these metaphors/models emphasize and put in the centre of our attention different characteristics of the museum and of museum work.

Without detailing the approaches mentioned here, let me start from the premise that the museum is first of all a station or a hub that defines the movement of the tourist or the visitor sensitive to the arts and the past (Frazon, 2003: 228). It is a space and a structure producing a public sphere where social communication is taking place, interpretations are emerging, and meanings are produced. As noted by Zsófia Frazon:

museums are institutions of social communications, and as such they produce or generate ideas, narratives, meanings, and interpretations from

1 In one of his studies, building upon the thoughts of Nelson Graburn, Zoltán Fejős calls attention to the fact that museum collections were in most cases born as a result of travels (e.g. ethnographic collecting trips), and these collections themselves become, in their turn, travel destinations. While previously museums have served as idiosyncratic substitutes for travelling (and, in a certain sense, continue to serve as such even today), they also send their exhibitions to travel. All these travels, with various purposes and taking different shapes, inevitably produce encounters that call to life various meanings/interpretations. See Fejős, 2000.

2 In this perspective, the museum is a "location for the cultivation of heritage", a cultural machine for presentation and interpretation, which collects, preserves, and mediates the cultural heritage of humanity. For more details, see Gagyi, 2008: 77 and Binni-Pinna, 1986.

3 The museum interiors that use panoptical techniques are also close to this concept. 
the objects and sources at their disposal. Through its exhibitions, the museum talks about that which - according to it - is important, valuable, and to be appreciated as well as about that which can be regarded as having national or regional character and is authentic. The museum is a forum for the communication and debate about science, society, politics, and economics. (Frazon, 2003: 230) ${ }^{4}$

Moreover, as mentioned above, museums are also heritage factories, where we may witness not only local/regional, national, ethnic, sexual, confessional, social, etc. identity formation/emergence, but which also function as complex spaces/contexts of the construction of meaning. The museum simultaneously produces the authentic and exotic past, strengthens community conscience, and offers visibility to the Other and to the past (viz. the past situation; the others, past self) that has been transcended by the community that constructed and sustains the museum.

As such, museums preserve the past, and the exhibitions explore and produce meanings already through the gesture of selection. They build identities, teach and entertain, bring close faraway worlds and cultures, establish and boost the tourism of certain cities or regions while also contributing to the functioning of economy.

As early as the second half of the 1960s, ethnographic museums were criticized for having become dubious institutions which had lost their function. ${ }^{5}$ Even if not explicitly stated, these critiques hint at the fact that (ethnographic) museums, viz. museums which (also) present ethnographic material, may be in many ways also conceived of as storage closets or, to put it even more strongly, as the final stages of consumption, as landfills. Indeed, the main characteristic of the material collected and exhibited in the ethnographic museum is that it consists of objects of use which have fallen into disuse, having mainly a documentary and no aesthetic value (Fejős, 2003a: 62). These objects acquire their final meaning in consumption and in living everyday life, a fact which, in most cases, also destroys them in the long run. In the context of folk/peasant life, most objects are open to their own contexts and are destroyed during their use: they deteriorate and become worn out (i.e. they cease to reproduce certain meanings). ${ }^{6}$ Consequently,

4 The translations of all non-English quotations belong to the author throughout the article.

5 The reason for this is to be found, first of all, in the fact that the object stock of ethnographic museums was, in the main, not collected by professionals, and the recording of even the most basic data about the objects was often omitted. Secondly, within the field of ethnographic/ anthropological research, the examination of material culture is continuously losing ground in favour of social-ethnographic research. Thirdly, the role of ethnographic museums is negatively affected by their loss of relevance for the ethnographic/anthropological research of material culture. See Sturtevant, 1969.

6 For more details on the evolution of the use ("biography") of objects from the folk/rural environment, see Hofer, 1983: 39-64. 
the ethnographic museum offers a new chance, a possibility for objects which ceased to make part of the consumption process, so that they can survive their own contexts. These objects are filled with new meaning through their collection, preservation, and presentation in the museum context.

\section{The Effect of the Covid-19 Pandemic on Museums}

In the past more than six months, not only the cultural institutional network but also - admittedly with some mild exaggeration and pathos - all of humanity has entered a peculiar existential state. For reasons of simplicity, let us refer to this state as the pandemic situation. This specifically means that all that was previously commonplace and accepted - or natural, if you like - has become in many ways impossible or, in some cases, even illegal. Our natural way of life has become trapped. Similar to the vast majority of cultural institutions, museums have been forced worldwide to close their gates in front of the public (while in the last one and a half hundred years all efforts have been directed at making them as open as possible).

Although the most prestigious institutions of the Western world reacted very quickly to this new situation and started to present themselves even more powerfully than before in online spaces and social media (organizing online presentations, guided tours, and even a series of exhibitions specifically created for online viewers), even these museums were strongly challenged. In Romania, including the Transylvanian region, the pandemic has almost completely halted the functioning of museums.

The pandemic has caused a regression ${ }^{7}$ in Transylvanian museum practice, a backward step towards a previous practice. The recent period reminded in many ways of the practice of the 1980s and 1990s, when (partially due to the lack of material resources) museums were unable to conduct any serious collecting work and to organize major exhibitions. Museums have suddenly re-become treasuries, ${ }^{8}$ archives preserving objects and meanings, and it will take time for them to recollect themselves and start searching for solutions.

$7 \quad$ According to Hermann Bausinger, regression does not only mean the revival of older attitudes that have meanwhile become obsolete and were superseded but also a return "to the genetically older and thus to deeper psychological strata", which, "lending regression, is not only an anchoring in the past but also a dangerous power". For more details, see: Bausinger, 1995: 45.

8 One should not forget that the precursors of museums, the collections known in the Germanspeaking world as Kunstkabinett, Kunstkammer, or Wunderkammer, were spaces closed for the wider public. 


\section{Museums and Digitalization}

The closing of the gates of the institutions did not always mean that the objects preserved in museums and the representations, knowledge forms, and interpretations constantly reproduced through the exhibitions would become completely inaccessible. In recent decades, the efforts directed at the digitalization of museums (museum objects and representations) not only opened the gates of these institutions but also created a museum without walls.

This period of digitalization and transmigration of museums into online spaces also showed the extent to which online/virtual spaces may or may not be regarded as natural mediums of museum representation. While online presence has never been so important for museums, the pandemic situation also showed the limits of this presence. The digital/online/virtual museum offering programmes for the viewing of the digital copies of museum objects, for their sorting according to different criteria as well as for virtual guided tours is at the same time something more and something essentially less than the museum that can be actually visited in the physical space.

Thus, the closing of the gates has not only caused an even stronger opening and shift towards online spaces, but it also (re)openend some classic questions. The most important of these is the simple but always timely question related to the purpose of museums - more specifically: what is the museum good for if the objects it contains are not directly accessible for the visitor (within the framework of exhibitions) $?^{9}$ This question is ultimately related to the social role of the museum, viz. its function within the communication that builds and organizes society. It seems that in this "unnatural" period of museums (for which there are no functioning, i.e. well-established and controlled practices ${ }^{10}$ the classic tasks of these institutions - their earliest functions, which have been already at work at their birth -, such as depositing and preserving, are becoming the most important, and the gesture of preservation may also be considered a compensatory practice in this context. Indeed, according to Odo Marquard (2001), the gesture of preservation is a compensatory practice, nourished by our growing insecurity about the usefulness (usability) of the fragments of the past that are left to us. In other words, while previously we only preserved what was important,

9 This question could be put in a different way as well, namely: what is the use of the objects hiding in museum storages for decades, with merely a few data recorded about them, which have minimal chances for being included in exhibitions and becoming accessible to the wider public?

10 Since the beginning of the writing of this study, museums have reopened their gates in many countries - including Romania - only to close them again almost immediately. Consequently, I do not believe that the former conditions/situations upon which the museum politics and museum interpretation of the past decades was built will be available again in the near future. The world of the museums is forced to develop new strategies and practices if it wants to preserve its role in anchoring culture and identity- as well as society-building communication. 
now we are increasingly preserving everything left to us. This is due to the fact that we are more and more unsecure about what we will need in the future for constructing our identity. Hence, preservation acquires its rationale from our insecurity about the future, and it is this insecurity that feeds the imperative of preserving everything. Since the future becomes even more uncertain in this pandemic situation, there is an even greater responsibility on museums as spaces of cultural and identity production and places of security and trust.

\section{The Limits of Museums without Walls}

Museums are usually located in the busiest urban areas, and the pure dimensions of these buildings and their impressive inscriptions draw our attention to them. Even if I, as a tourist, do not exactly know what treasures the institution is hiding, it still catches my attention, attracts and invites me in. By contrast, it is largely haphazard who and how will access certain virtual museum exhibitions. In the jungle of myriad websites, I am most likely to access and come into contact with those institutions about whose existence I already have some previous knowledge.

The online medium by itself (the museum's website, the virtual guided tours, and social media) is incapable of performing on its own the tasks of the museum. The system can only function if the institution can also be visited in its physical form. This phenomenon could be termed as "the unbearable lightness", or weightlessness, of the online medium, and the crucial point is that without actual physical connection, the museum is unable to fully perform its essential function. To put it more strongly, the online space remains foreign to the spirit of the museum, and it is not a natural medium of museums.

It is another matter that, while museums could actually be visited in their physical form, and there were temporary exhibitions, ushers, actual guided tours, etc., it seemed that all is well with virtual museum tours. I myself was very happy that, similarly to the Western giants, our Eastern European and, in particular, Romanian museums are discovering one after another the possibilities offered by the online space. Indeed, I certainly maintain that this is a good thing, and it is needed.

However, Inow also see where the limitations of this online world lie. The social media and the various online applications, while most usefully complementing the activities going on in the physical space of the museum and helping the museums to nurture their reputation and establish connections, as well as aiding visitors in orienting themselves, cannot ensure the (in my opinion) primordial functions of these institutions (the experience of recognition stemming from the joy of the encounter, the emergence of the meaning of the objects in this particular context, and the joy/experience it emanates, which also contains an element of learning and identity formation/preservation). 
It is for this reason that I venture to say that in this not at all natural world (i.e. a world that is not based on long-established traditions, is not relatively stable, planned, and predictable) preservation is becoming again the main task of museums. Considering that in the last six months the revenues of most museums have decreased significantly, which in many cases also led to drastic staff cuts, the above statement may become even more acceptable. Museums, which are fighting the problem of declining revenues, are increasingly viewed as a burden by their funders, what not only threatens with the loss of prestige, but, in many cases, the very existence of the institution also becomes questionable. It is partly due to this reason that, over the last decade, the entertainment function of the museum has increasingly come to the fore, at the expense of the preserving function, so much so that, according to the public view - and the opinions of many specialists are quite close to this view -, entertainment can be regarded as one of the main tasks of the museum. This may partially be due to the fact that it is entertainment mainly through tourism - that can be best integrated into the logic of the funders and is in many ways most readily accepted by the majority of the society as well.

At the same time, the vigorous relocation into the online space and the strengthening of the preserving function also means, in some sense, a state of waiting: due to the pandemic situation, museums cannot do anything else but wait for the possibility to open their gates again to their visitors, even if this does not mean that everything will immediately go back to normal. New rules for the use of time and space will take effect, and some services (e.g. luggage storage) will not be available yet.

Nevertheless, there is a silver lining: museums were given a small breather to redesigning themselves and to examine their ideas related to digitalization (viz. its advantages and disadvantages) as well as to find a new kind of balance between physical and online presence at the threshold of a new era.

\section{The New Challenges of Digitalization and Virtualization}

In connection with the spread of panoptic-like solutions in museum interiors, G. Péter Tóth states that "it is by now almost certain that we may bury the traditional genre of the museum interior", with exhibition spaces turning from locations of "silent contemplation" into "total spectacle" (Tóth, 2011: 45). However, the process does not stop here. The digitalization of museum interiors and exhibitions is just a milestone on the road to the eradication/disintegration of traditional museum concepts, reaching their climax in the "digital transition" that took place during the quarantine period. It was the closing of the museums and the transfer of museum activities into the online space which showed it most distinctly how 
much the visitor needs silent reflection and how much the possibility of this reflection is tied to the actual walls of the museum and to those physical spaces where the preservation of the objects and the production of meaning is/was taking place. The silence of virtual spaces cannot reconstruct the silence preserved/ created by the walls of the museums located in the tourist-filled noisy squares of the metropolises. While it is true that, thanks to digital technology, the viewer may frequently discover details and connections which would hardly be accessible in the actual museum spaces for the naked eye, the "spirit of the place" and its mood cannot be fully reflected by the digital copy of the museum object or by the virtual exhibition. More exactly, another kind of reception is taking place because of the virtual nature (immateriality) of the exhibition.

This alterity is also due to the fact that the story represented in the space of the museum acquires its way of reading from the location, which makes it possible for the visitor to become an active part of the narrative that is represented (Tóth, 2011: 45-46). What happens if this story is represented in the digital space? Does it make the same way of reading accessible? Does the "on-site" visitor participate in the same way in the narrative as if s/he walked through the physical space of the museum? Hardly.

The viewing of an exhibition organized at a memorial site or the visit to a traditional country house allows for a different kind of reception than the viewing of the digitalized version of an exhibition, which is accessible in the online space. While the former is closely connected to the place and the narratives preserved/ encoded in it, this connection is less evident in the case of the virtual version. On the one hand, the visitors of the exhibitions accessible in the online space are visiting these virtual spaces with intentions of another kind. While the act of viewing has a kind of ritualized character in the former case, this attitude is less present in the latter. On the other hand, while it is indisputable that the museum exhibition built in the online space is able to tell its stories efficiently and graphically, it is a huge disadvantage compared to the traditional/actual museum exhibition that it is not able to create a real space but only a fictional one. As much as it may refer to a specific (memorial) site, it will always remain to some extent a non-place (Auge, 1995), which "condemns us to loneliness and causes anxiety" (Horányi, s.a.).

Besides the connection between the space and the story, the issue of authenticity is also significant. From this perspective, it seems that, while even the poorest execution is able to offer a sense of authenticity in the museum setting, the construction of this authenticity is an almost impossible task in digital/virtual spaces. In other words, the museum setting is able to create authenticity, but the narrative it creates remains in many ways boring. By contrast, the virtual space may construct a very interesting story, but it is unable to offer a sense of authenticity to the visitor. 
As already noted above, the museum fulfils an important role in socially constructive communication. It does not only render the past that we have left behind visible and help us to understand and accept the past and another culture, as well as to connect them with processes going on in the present, but it is also a space which "offers a scientifically-based and experiential representation of culture, arouses interest for the representations, and creates a constructive dialogue" (Frazon, 2003: 231). In this approach, representation is "a social representation of reality", which, on the one hand, may be regarded as "a manifestation of the institutional state", and, on the other hand, as "the representation of topics, the transformation of phenomena and processes into topics (...), an instrument of the institutional communication strategy" (ibid.).

The curatorial practice built on participation emphasizes the actualization of the principle of general accessibility and open dialogue. While the digitalization of museums enables the actualization of this principle, the online space presents at least as many obstacles as the possibilities it promises from the perspective of accessibility. The Internet, the various online platforms and immersive technologies render even faraway institutions accessible, but this type of accessibility is strongly dependent upon device, energy source, and Internet access, not to mention the knowledge/competence necessary for using the technology.

\section{Closing Remarks}

Over the past six months, we could and still can witness the changes regarding museums and museum environments, and we ourselves, who inhabit/use the spaces of the museums, have also changed. These changes affect the frameworks of representation and reception as well as our habits of viewing and interpretation. The mass museum visits - taking place in the context of cultural heritage and urban tourism - that have become the general practice during the last decades and offered the museums their lifeblood currently seem to transform/disappear. Instead of/besides tourists coming from far away, with a foreign cultural background, natives, i.e. the locals, are moving (again) into the focus of the museums, and curators, as the gaze of the local visitor, come to the fore and are re-appreciated. All this implies the necessity of creating concepts and narratives of a different kind. At the same time, it is also clear that these changes affect very differently the life and the world of the museums of the metropolises and those of provincial museums (cf. Frazon, 2003: 232).

Besides/instead of increasing the number of visitors, the issues of security and of following the epidemiological and health rules become acute. However, the uncertainty created by this situation also offers a possibility for Transylvanian 
(minority) museology for turning towards professional issues as well as for mapping and integrating the international theoretical literature on museums and museum practices. It offers a chance for experimentation and innovation, for constructing the museum practices associated with online spaces according to international models, and for conquering the online world. ${ }^{11}$ In this regard, museums and museologists must also rely upon the results of communication science and upon the research of new media.

At the same time, the museum as a space and an institution is also connected with several professional roles besides that of the museologist, from the usher ${ }^{12}$ to the museum educator, the curator, and the PR specialist. The relocation of museums into the online space - even if it is forced by necessity - affects these professional roles. Due to the fact that physical spaces become inaccessible and the encounters hosted by them are eliminated, the organization of new exhibitions and the generation of new art projects, as well as their contextualization, takes a different, unusual form. The online space provides different tools, with differences in both quantitative and qualitative terms, which allows for a presence and meaning generation of a different intensity and quality. While the space expands (there is almost no limit for the exhibition space and for the number of rooms that can be created, and the time allocated for viewing/museum walkthroughs is also theoretically limitless), the time allocated to viewing is actually shortened and becomes fragmented. The attention of the visitor is divided between many homepages and between two worlds (the virtual world and the real one).

\section{References}

Auge, Mark. (1995). Non-Places. Introduction to an Anthropology of Supermodernity. London-New York: Verso.

Bausinger, Hermann (1995). Népi kultúra a technika korszakában [Folk Culture in the Age of Technology]. Budapest: Osiris-Századvég.

Binnni, Lanfranco-Pinna, Giovanni. (1986). A múzeum. Egy kulturális gépezet története és múködése a XVI. századtól napjainkig [Museum. The History and Operation of a Cultural Machinery from the $16^{\text {th }}$ Century to the Present]. Budapest: Gondolat.

Fejôs, Zoltán. (2000). Múzeum, turizmus. A kulturális találkozás és reprezentáció rendszere [Museum, Tourism. The System of Cultural Encounter and

11 I would also like to mention here that critical analysis can also not be omitted during the adaptation of these international models.

12 According to Johan Idema, "the usher is the most conspicuous and, at the same time, the most invisible person in the museum". Nevertheless, they are "foot soldiers of art" and "the eyes of the museum", from whom we may learn quite much about the museum and its life as well as about the artworks. For more details, see: Idema, 2019. 
Representation]. In: Fejős, Zoltán-Szijártó, Zsolt (eds.), Turizmus és kommunikáció [Tourism and Communication]. Néprajzi Múzeum-PTE Kommunikációs Tanszék: Budapest-Pécs, 236-252.

(2003a). Tárgyak, anyagi kultúra, reprezentáció [Objects, Material Culture, Representation]. In: Fejős, Zoltán, Tárgyfordítások. Néprajzi múzeumi tanulmányok [Object Translations. Ethnographical Museum Studies]. Budapest: Gondolat, 53-65.

(2003b). Múzeum, turizmus. A találkozás és a megmutatás kapcsolatai [Museum, Tourism. The Relationship between Encounter and Showing]. In: Fejős, Zoltán, Tárgyfordítások. Néprajzi múzeumi tanulmányok [Object Translations. Ethnographical Museum Studies]. Budapest: Gondolat, 131-154. Frazon, Zsófia. (2003). Múzeumi reprezentáció, nyilvánosság és turizmus [Museum Representation, Publicity, and Tourism]. In: Fejős, Zoltán-Szíjártó, Zsolt (eds.), Helye(in)k, tárgya(in)k képe(in)k [(Our) Places, Objects, Images]. Budapest: Néprajzi Múzeum, 228-246.

(2011). Múzeum és kiállítás. Az újrarajzolás terei [Museum and Exhibition. The Places of Redrawing]. Budapest-Pécs: Gondolat-PTE, Kommunikáció- és Médiatudományi Tanszék.

Gagyi, József. (2008). Örökség és közkapcsolatok (PR) [Heritage and Public Relationship]. Cluj-Napoca: Scientia.

Hofer, Tamás. (1983). A „,tárgyak elméleté”-hez. Felszerelések és tárgyegyüttesek néprajzi elemzése [To the "Theory of Objects". The Anthropological Analysis of Utensils and Groups of Objects]. In: Kósa, Lászó (ed.), Népi kultúra-Népi Társadalom [Folk Culture-Folk Society]. Az MTA Néprajzi Kutatócsoportjának Évkönyve XIII. Budapest: Akadémiai Kiadó, 39-64.

Horányi, Anna. (n.d.). Identitás-viszonyok és magány mindennapi tereinkben. M. Augé: Nem-helyek. Bevezetés a szürmodernitás antropológiájába [Identity Relations and Loneliness in our Everyday Spaces. M. Auge: Non-Places. Introduction to an Anthropology of Supermodernity]. Új Forrás. http://ujforras. hu/identitas-viszonyok-es-magany-mindennapi-tereinkben/ (last downloaded on: 26.09.2020).

Idema, Johan. (2019). Hogyan látogassunk múzeumot. Tippek az igazán élvezetes látogatáshoz. [How to Visit an Art Museum. Tips for a Truly Rewarding Visit]. Budapest: Scholar.

Marquard, Odo. (2001). Az egyetemes történelem és más mesék [Universal History and Other Stories]. Budapest: Atlantisz.

Sturtevant, William. (1969). Does Anthropology Need Museums? In: Proceedings of the Biological Society of Washington 82: 619-649.

Tóth, G. Péter. (2011). Múzeumi enteriőr - historical reenactment - kínzókamrapanoptikum. Középkori váraink turizmusipari használata [Museum Interior - Historical Reenactment - Torture Chamber Panopticon. The Use of Our 
Mediaeval Castles in the Tourism Industry]. In: Fejôs, Zoltán (ed.), Színre vitt helyek [Staged Places]. Budapest: Néprajzi Múzeum, 41-61.

\section{Cite as:}

Vajda, A. (2020). Museums and Online Spaces. The Society-Building Role of the Museums during the Pandemic. Acta Universitatis Sapientiae, Communicatio 7: 72-53. DOI: 10.2478/auscom-2020-0004. 